\title{
ASPECTOS DA CRÍTICA DE FRANCISCO JOSÉ DE JACA À IDEOLOGIA DA ESCRAVIDÃO NA ESCOLÁSTICA COLONIAL
}

\author{
ASPECTS OF THE CRITICISM OF FRANCISCO JOSÉ DE JACA \\ TO THE IDEOLOGY OF SLAVERY OF IN COLONIAL \\ SCHOLASTICS
}

Joel Decothé Junior*

Recebido: 06/2017

Aprovado: 10/2017

\begin{abstract}
Resumo: Neste texto propomos a realização da abordagem preliminar do problema da ideologia da escravidão presente nos debates da escolástica colonial. Este foi um dos problemas que atingiu desumanamente as colônias da América espanhola e portuguesa. Assim, temos o interesse de estudar a ideologia da escravidão colonial negra, que abarca os debates ocorridos nas disputas sobre licitude e ilicitude da mesma nas colonias espanholas. Isto implica em múltiplos argumentos que compõem o pensamento sobre o tema da escravidão tanto indígena como negra, que foi tratado por filósofos e teólogos atuantes na história da filosofia escolástica colonial do Novo Mundo. Nesta sociedade, o tráfico sistemático de escravos gerou relações de injustiça e hierarquias que dizimaram um número incalculável de vidas, e que sem dúvida nos legou os seus reflexos em termos de desigualdade social nas relações de raça e etnia desenvolvidas em nosso continente latinoamericano. Perseguindo esta controvérsia, tentamos nos apropriar e elucidar o problema da manutenção desta ideologia, que de uma forma paradoxal, buscou legitimar a substituição da escravidão indígena pela escravidão negra. Isto tudo no sentido de buscar-se justificar a ideologia da escravidão negra, como um tipo de prática que fosse legalmente chancelada por meio da licitude conferida por uma série de títulos. Contra estas injustiças, abordamos alguns aspectos da crítica inovadora presente na proposta antiescravagista de Francisco José de Jaca OFMCap (1645-1689). Logo, cabe frisar que o frade capuchinho se insurgiu contra tal prática da ideologia da escravidão, com a sua proposta de liberdade natural e justiça restitutiva, que visa corrigir os danos causados aos povos negros vindos da África que foram submetidos a trabalhos forçados. Então, esta crítica pode ser encarada como um protótipo da gênese dos direitos humanos, que visa fazer a defesa da vida em sua integralidade, sem nenhuma distinção de etnia, cor ou raça.
\end{abstract}

Palavras-chave: Crítica; Ideologia; Escravidão; Colonial; Escolástica.

\begin{abstract}
In this paper we propose the preliminary approach to the problem of the ideology of slavery present in the debates of colonial scholasticism. This was one of the problems that inhumanly hit the colonies of Spanish and Portuguese America. Thus, we have the interest of studying the ideology of black colonial slavery, which encompasses the debates that took place in the disputes about the lawfulness and illegality of the same in the Spanish colonies. This implies multiple arguments that compose the thinking on the subject of both indigenous and black slavery, which was treated by philosophers and theologians active in the history of colonial scholastic philosophy of the New World. In this society, the systematic slave trade generated relations of injustice and hierarchies that decimated an incalculable number of lives, and which undoubtedly bequeathed us its reflections in terms of social inequality in the relations of race and ethnicity developed in our Latin American continent. Pursuing this controversy, we tried to appropriate and elucidate the problem of maintaining
\end{abstract}

\footnotetext{
* Mestre em filosofia pela Universidade do Vale do Rio dos Sinos (UNISINOS). Especialização em teologia luterana pelas Faculdades EST (EST). Licenciado em filosofia pela Universidade do Vale do Rio dos Sinos (UNISINOS). Bacharel em teologia pelas Faculdades EST (EST).

Problemata: R. Intern. Fil. v. 8. n. 3 (2017), p. 20-39 ISSN 2236-8612

doi:http://dx.doi.org/10.7443/problemata.v8i3.34926
}

Problemata: R. Intern. Fil. v. 8. n. 3 (2017), p. 20-38

ISSN 2236-8612 
this ideology, which in a paradoxical way, sought to legitimize the replacement of indigenous slavery by black slavery. All this in the sense of seeking to justify the ideology of black slavery as a type of practice that was legally barred through the lawfulness conferred by a series of titles. Against these injustices, we approach some aspects of the innovative critique present in the anti-slavery proposal of Francisco José de Jaca OFMCap (1645-1689). It should be pointed out that the Capuchin friar rebelled against such a practice of the ideology of slavery, with its proposal of natural liberty and restorative justice, which seeks to correct the damage done to black people from Africa who have been subjected to forced labor. So this criticism can be seen as a prototype of the genesis of human rights, which aims to make the defense of life in its entirety, without any distinction of ethnicity, color or race.

Keywords: Criticism; Ideology; Slavery; Colonial; Scholastics.

\section{Considerações aproximativas ao problema da práxis da ideologia da escravidão colonial}

Ao pensarmos nos desdobramentos referentes aos progressos da vida econômica e social dos vice-reinados do novo mundo transatlântico, e na expansiva progressão e implantação do cristianismo nestas terras, surgiu como resultado natural, uma série de aporias éticas a respeito dos justos títulos de conquista e da escravidão dos afro-americanos, de modo que como consequência os filósofos e teólogos deste tempo histórico, começaram a refletir sobre a utilização de seus trabalhos forçados nas lavouras e minas locais. Isto foi algo que fez eclodir o problema e a polêmica sobre o método de evangelização pacífica nos seio dos debates de filosofia prática na chamada escolástica colonial no século do Barroco hispânico-português (SARANYANA, 2006). A partir da segunda metade do século XVI, e especialmente no século XVII, sob a autoridade dos clássicos da filosofia antiga, patrística e escolástica medieval. Várias abordagens sobre o estatuto e a prática da escravidão semelhante à que a anterior geração tentou dar cabo por suas próprias contas, moveu os intelectuais católicos a enfrentaram questões morais tanto teóricas como práticas relativas à escravidão dos "africanos" ou mais geralmente falados, dos "negros" e a correção moral e jurídica da instituição que regulava a vida dos escravos (PICH, 2015, p. 51-52). O problema da escravidão no século dezessete é sem dúvida uma aporia que a filosofia e teologia escolástica colonial latina tiveram de enfrentar, isto se deu com uma diversidade ampla de posições teóricas que nem sempre foram convergentes em termos de comércio e suas várias implicações.

O paradoxo ideológico da escravidão colonial é um tema que nos mostra o quanto não existiu certa linearidade no tratamento do problema, pois para alguns escolásticos a defesa da liberdade dos indígenas era um imperativo moral de primeira ordem, porém e simultaneamente, este mesmos 
pensadores prescreviam a escravidão dos povos negros africanos como base de sustentação do sistema social e econômico colonialista, mesmo que cada um desde pensadores tivesse a sua forma teórica de tratar o tema. Contra esta maneira de ver este estado de coisas é que se levanta o frade capuchinho aragonês Francisco José de Jaca com a sua crítica pertinente a ideologia da escravidão dos povos de matriz africana. Os autores que tratam do tema da escravidão colonial negra à época, estão preocupados em justificar por meio de títulos esta sistema de subserviência, porém, como consequência disto, o que eles tratam é de apenas de apaziguar as consciências dos escravocratas por meio da discussão da legitimidade ou não destes títulos de escravidão. Contudo, e, ao contrário desta postura, temos a inovadora dialética crítica que além de ter sido encetada por Francisco José de Jaca, também teve força na ação abnegada do frade Epifanio de Moirans OFMCap (1644-1689) em suas práticas e escritos, conforme argumenta Montes D'Oca:

\begin{abstract}
Dito de modo muito breve e em linhas muito gerais, esses autores condenaram a escravidão ocorrente sem justo título (i.e.: de modo ilegal) e censuraram 0 tráfico de africanos que tivessem sido injustamente escravizados. Ademais, condenaram as condições subumanas e degradantes a que os africanos eram submetidos, bem como os múltiplos maus tratos e comportamentos inadequados cometidos pelos senhores de escravos. No entanto, nenhum desses autores fez uma verdadeira e radical defesa da liberdade dos escravos africanos. Ao contrário, muitos só pareceram ter se preocupado em tranquilizar a consciência dos senhores de escravos. Todavia, esse modo de encarar o tema da escravidão negra só parece ter perdurado até o aparecimento, no último quartel do séc. XVII, de dois missionários que, conhecendo em primeira mão a crueza da realidade da escravidão e protestando contra essa realidade, redigiram dois tratados específicos sobre o tema consagrados a condenarem de modo peremptório a escravidão negra. Esses missionários são o frade aragonês Francisco José de Jaca OFMCap (1645-1689), autor da Resolución sobre la libertad de los negros y sus originarios, en estado de paganos y después ya cristianos, e o frade borgonhês Epifanio de Moirans OFMCap (1644-1689), autor do tratado Servi liberi seu naturalis mancipiorum libertatis iusta defensio (MONTES D'OCA, 2017, p. 282).
\end{abstract}

O pensamento antiescravagista de Francisco José de Jaca é uma inovadora e fundante manifestação crítica de oposição da instituição da escravidão que era praticada contra os povos negros africanos. O frade capuchinho unido ao ser irmão de ordem se constitui como um dos primeiros pensadores da época que faz uma crítica ferrenha a ideologia da escravidão, e propõe a libertação destas pessoas que são vítimas da escravidão institucionalizada em pleno século de Ouro espanhol. A sua proposta de resolução visava a liberdade dos povos negros e indígenas, tomando como 
base um posicionamento que postula a vigência dos axiomas da igualdade e da liberdade em termos de direitos humanos de ordem e sentido universal. Assim, buscamos nos aproximar do contexto moral colonial escravagista no período do barroco e da aporia ideológica de instituição sistemática da escravidão negra africana, levando ainda em conta, proposição crítica e inovadora que se ergue como antiescravagista desde o pensamento de Francisco José de Jaca que certamente foi um dos primeiros defensores dos direito humanos, da justiça e da liberdade na história desta época paradoxalmente denominada de ouro.

\section{A ordem moral colonial fechada em razão do sistema escravagista vigente no século do barroco}

A escravidão desde a antiguidade clássica se constitui como uma prática que visou beneficiar apenas as estruturas e sistemas socioeconômicos que acabaram sendo legitimados por códigos jurídicos presentes nas mais diferentes estâncias coloniais do continente americano no século XVII. Esta prática sistemática de gestão da vida foi imposta aos povos originários e as mais diversas etnias negras de origem africana de uma forma avassaladoramente violenta. Aqui temos um estado de coisas que gerou uma série de implicações injustas para as gerações futuras, pois estes povos escravizados foram ocupando um lugar que pode ser lido como o espaço da escória e da invisibilidade da dignidade humana. Logo, nas sociedades coloniais hispano-americanas os axiomas do iluminismo europeu, a saber, os de liberdade, igualdade e fraternidade que são símbolos da cultura ocidental podem ser questionados quando pensamos nas atrocidades realizadas pela máquina ideológica da escravidão. Esta montou uma ordem moral colonial fechada, hierarquizada e sistematicamente movida pelo modelo de produção escravocrata. Assim, "faz-se urgente a realização de estudos filosóficos que analisem a implantação da empresa escravagista e a gênese de sua desestruturação na América espanhola como uma tarefa atualíssima" (BELTRÁN, 2014, p. 70). Podemos contabilizar três séculos de história colonial de pensamento filosófico, onde a ideologia da escravidão agiu com severidade institucional sendo respaldada com as devidas alegações de legitimidade éticojurídicas que envolveram tanto o poder da igreja como das coras à época.

Em certa medida, podemos articular a noção de que no período inicial desta ideologia busca-se conquistar e logo em seguida pacificar os territórios colonizados no século XVI. Em seguida, temos o estabelecimento e operação de uma ordem moral escravagista colonial severamente fechada às novas possibilidades nascentes no século XVII. Por fim, temos a desconstrução desta 
ordem moral escravocrata e a abertura de novos horizontes emancipatórios no século XVIII, sendo algo que resulta na constituição dos modelos de Estado independentes que foram sendo erguidos nas primeiras décadas do século XIX. No contexto histórico ideológico escravagista da ordem moral fechada vigente no século do barroco quando pensamos no ocaso do século XVI, o império do rei Felipe II se estendia de norte a sul de todo o continente do novo mundo, inclusive abrangendo o Brasil, dado que os reinos de Portugal e Espanha mantiveram certa unidade monárquica até o ano de 1640. Com o advento do século XVII as potências nascentes tais como a Inglaterra, França e Holanda lutavam para conseguir um pedaço de terra colonizada no novo mundo. Aqui acontece um deslocamento nos valores morais, pois estas nações não respeitavam mais a autoridade territorial da igreja que até este momento legitimava o domínio e monopólio das Índias por parte dos reinos de Portugal e Espanha.

Tendo em vista uma eficaz administração do vasto território do império criou-se um expediente hierarquizado que estava centro na monarquia, onde a autoridade se dava de forma absolutista desde a capital da metrópole. Isto acontecia mediante três esferas institucionais: (i) por meio da casa que estabelecia contratos lavrados e que por isso controlava o comércio; (ii) pela via do conselho das Índias, onde se detinha o poder de fazer a gestão das rendas do governo civil e judicial; (iii) por meio do padroado regente que estava encarregado de gerir todo tipo de assunto de ordem puramente religiosa. A este sistema metropolitano de poder estavam subordinada todas as instituições que compunham a ordem moral colonial, sendo tais como os vice-reinados, as presidências, os governadores, as capitanias, as audiências reais, os ajuntamentos e conselhos municipais seja na esfera civil ou na dimensão da vida religiosas das dioceses ocidentais. Ademais, após as desordens que o período de invasão violenta gerou o que se impôs foi um arranjo social de ordem disciplinar colonial que se tornou inevitável, e que consequentemente constituiu-se num complexo regime fechado de territórios dominados pela política escravagista instaurada pela cora espanhola.

Este tipo de ordem social moral fechada tem as suas fronteiras marcadas pela premissa do protecionismo de seus bens e territórios, pois o objetiva era o de travar a inserção das influências externas das nações alheias que estavam em plena expansão. Esta é uma faceta do problema que tem a sua base política, pois temos outro aspecto que é de ordem religiosa. Aqui a apologia se dá com a proteção da fé católica de seus habitantes das influências dos chamados hereges protestantes. Tal postura faz com que muitos dos avanços modernos retardem sua chegada nestas regiões de colonização. Uma circunstância que ilustra bem isso é a de que com a tomada do trono imperial por parte de Felipe II no ano de 1556, acontece "a proibição de se estudar nas 
universidades estrangeiras, o primeiro auto de fé de Valladolid e a aparição do primeiro Índice de livros proibidos." (ARGOTE, 1994, p.16). A empresa da Inquisição operou de forma central no movimento de oposição ao avanço protestante com a instauração da contrarreforma, fechando ainda mais o cerco desde os ângulos político, cultural e eclesiástico. Evidentemente, a vida cultural no império colonial espanhol não estagnou totalmente durante a primeira parte do século XVII, porém este tipo de desaceleração aconteceu muito mais devido as motivações ortodoxas do século XVI. Um dos problemas que estavam na pautados foi resolvido, a saber, o da questão que tratava da escravidão indígena. Logo, na ordem social colonial barroca se estabelece um modelo piramidal de hierarquia e vida em sociedade, que tem como critério de definições das posições de casta a origem das pessoas e a sua cor de pele de seus membros.

Neste modelo de sociedade escravocrata e hierarquizado, as pessoas negras ocuparam a última posição na condição de matéria prima escrava. Este processo de condicionamento das pessoas negras nesta posição social durou quatro séculos, um contingente imensurável destas pessoas era transportado da África com toda a crueldade e vileza possível. Como consequência disto, boa parte das pessoas não conseguiu fazer este traslado e acabou vindo a óbito antes de aportar nas colônias espanholas, portuguesas, inglesas e francesas. As colônias hispânicas foram as que mais receberam pessoas escravas vindas do continente africano, desta forma, Cartagena das Índias se constituiu como um dos principais portos de trafico negreiro legitimado no Caribe que fez a recepção de contingentes e mais contingentes de pessoas negras para o trabalho escravo. Em meio a estes desdobramentos filosóficos e históricos, existiram grupos ativos de religiosos tais como os dominicanos, que são os primeiros autores que mencionam o tema da escravidão negra como problema por meio de seus representantes oficiais, tais como Domingo de Soto (1494-1560), Fernando Oliveira (1507-1581), Tomás de Mercado (15251575), e também o jurista Bartolomé Frias de Albornoz (fl.1553). Contudo, cabe frisar que os pensadores que argumentaram com maior propriedade sobre a temática, são aqueles que escreveram extensivamente sobre o assunto, neste no caso são os jesuítas, "encabeçados por Luis de Molina (1535-1600). E, depois de Molina, vários outros jesuítas que escreveram sobre isso: Tomás Sánchez (1550-1610), Fernando Rebello (1546-1608), Alonso de Sandoval (1576-1652) e Diego de Avendaño (1594-1688), para mencionar apenas alguns" (MONTES D'OCA, 2015, p. 91-92).

\section{A problemática ideológica de instituição sistemática da escravidão negra africana}


O processo de escravidão do povo negro africano está envolto em um paradoxo presente no campo da filosofia escolástica colonial, que pode ser formulado da seguinte forma: por quais razões os filósofos e teólogos desta época superaram a mentalidade de escravizar os povos indígenas, mas não conseguiram aplicar tais pressupostos éticos para a vida dos povos negros de África? Este é um problema que já se aventava desde a antiguidade clássica, pois existiam amplas reservas morais em relação os povos negros, porque estas pessoas não eram dignas de receber a confiança alheia. No ocaso do século dezesseis, ao tráfico negreiro foi ganhando cada vez mais fluxo monetário rentável com as negociações que os Corsos faziam com o mercado escravagista. Todavia, estas práticas de compra e venda de escravos foi amparada pelas legislações presentes no direito romano de corte espanhol que legalizava este tipo de comércio que não se restringia apenas aos povos africanos, mas abrangia todas as demais etnias. A prática que teve grande repercussão no prelúdio da escravidão negra foi a de que os primeiros escravos eram lavados para as Índias ocidentais como empregados pessoais de seus donos. Tal prática de subordinação se popularizou no tempo das primeiras navegações.

Seguindo esta linha de compreensão deste tipo de prática que envolve o paradoxo da escravidão, temos que ter em mente que desde os seus primórdios ao se perceber que os indígenas não conseguem manter o mesmo nível de resistência física dos povos africanos, "diversos setores do governo eclesiástico propuseram que houvesse a substituição da mão de obra indígena pela força de trabalho negra boçal vinda da Guiné" (GONZÁLEZ, 2014, p. 380). Isto é algo que será assegurado por leis monárquicas que vedariam a escravidão dos demais povos e concentrariam a sua dominação e manipulação de contingentes de pessoas negras para o trabalho escravo. Paradoxalmente, Las Casas que foi um defensor tenaz da causa de libertação indígena, num primeiro momento de enfrentamento desta aporia humanitária, propôs por volta de 1516 que a mão de obra indígena fosse substituída no trabalho das encomiendas, pela mão de obra do povo negro africano para que assim este trabalhasse de forma escrava nas novas terras descobertas do Novo Mundo, vemos isso conforme a ponderação de Ramos:

E contra o Negro as conclusões apresentadas são muito mais pessimistas que contra o indígena. A começar com aquelas providências advogadas pelos primeiros colonizadores nas Antilhas, pedindo a substituição da escravidão indígena pela negra. O padre Bartolomeu de Las Casas é apontado como um desses primeiros defensores dos índios clamando contra a cessão dos seus repartimientos e solicitando ao revés, a entrada de negros africanos para o trabalho escravo no Novo Mundo. (RAMOS, 
2004, p. 87).

Como vemos paradoxalmente a ideologia da escravidão negra foi defendida por Las Casas, mas este defensor da liberdade indígena não o único a fazer tal apologia. Contudo, não podemos deixar de lado o fato de que Las Casas foi um severo crítico das guerras promovidas nas Índias, pois para ele tal empreitada se choca diametralmente contra a noção de direito natural e divino, porque a escravidão em si mesma é naturalmente ilícita. Como consequência disto, recaí sobre as práticas escravagistas dos conquistadores, o peso destes estarem diante do dever de estabelecer a prática de restituição dos bens e das riquezas adquiridas, sendo tal máxima aplicável também aos governantes de modo que se não cumprirem este dever moral, esta governos deveriam ser substituídos por outros governos que sejam justos neste sentido. Esta postura paradoxal de proteção indígena que não se preocupava com a vida dos povos africanos, visava à implantação de uma espécie de justiça restituidora de bens, pois "os conquistadores deveria assinar uma declaração de restituição dos bens dos índios, onde o penitente devia confessar todos os pecados, especialmente, a guerra feita contra os índios, os assassinatos e roubo de mulheres etc." (BRUIT, 1995, p. 72). Com a justificação teórica de instituição da escravidão negra legitimada e tendo a nitidez dos impactos econômicos que foram sendo alcançados com o trabalho escravo do povo africano, o passo seguinte de se fazer comércio e tráficos de escravos não será uma tarefa complicada de ser aceita do ponto de vista moral, pois todo um sistema de navegação com navios negreiros entrará em vigo no Ocidente.

Mesmo diante destes fatos o que se ergue como ponto nodal de tal problemática, é a fundamentação teorética que esta instituição da escravidão na filosofia escolástica colonial sustenta como epistemologicamente válida. Assim, neste estado de coisas, não se pode esconder que é precisamente no século XVI quando a moral se articula com base na teologia, que ainda é encarada como área do saber que detém certa autoridade e relevância inquestionável. Temos que frisar que falamos aqui da filosofia-teologia produzida no mundo colonial da segunda escolástica, o que se constata como autoridade teórica notável é a dependência do tomismo e da filosofia aristotélica. No caso da defesa da escravidão como algo naturalmente intrínseco a sociedade, o filósofo que era útil para tal fundamentação foi Aristóteles, ainda que em tal perspectiva filosófica a escravidão fosse encara como algo contrário a natureza. Dois pensadores coloniais, a saber, Francisco de Vitória e Domingo de Soto seguem estas intuições, para Vitória o que gera a validade de tal instituição da escravidão dos negros era a vigência dos títulos de licitude escravagista. Sendo assim, Vitória leva em consideração que os povos africanos são considerados escravos de fato e de direito, pois o acento 
da licitude está posto de modo mais imediato na forma como se trata estes povos.

Se entendermos o posicionamento de Vitória como de ordem pessoal isto nos dá as condições necessárias para que percebamos a diferença bem nítida, existente entre os pensadores escolásticos Domingo de Soto e Luis de Molina. De uma forma bem fundamental vamos nos deter em alguns aspectos do pensamento destes dois escolásticos. O dominicano Soto toma como base para sua tomada de posição diante do problema da escravidão os títulos para justificar a prática e legitimidade da mesma. Soto argumentava criticamente contra aqueles que baseados na argumentação da guerra justa, vendiam crianças e jovens sem escrúpulo algum. Para este dominicano, o imperativo da liberdade é bem incalculável para a vida humana, e nesta linha ele parte desta noção de liberdade para fazer a defesa crítica dos povos africanos escravizados que eram enganados e maltratados com crueldade e de forma imoral. Soto entendia que as ações de todas as pessoas que "capturavam, compravam e se tornavam donas de escravos eram ilícitas, e que estas pessoas não podem ter a consciência tranquila, mesmo que depois de um tempo os libertem, pois os povos escravos jamais recuperariam o que foi perdido." (LÓPEZ, 1982, p. 22). O pensador escolástico dominicano denuncia que era um grande equívoco querer justificar a esta ideologia da escravidão dom o dado da fé catequética, pois ele considerava que este tipo de posição desqualificava os próprios elementos tendo em mento que não era possível acessar este universo de sentido por meio da violência escravagista.

Em Luis de Molina, temos uma articulação de argumentos que toma como base a prática de comércio de escravos feita por Portugal. Paradoxalmente, Molina acede a prática da escravidão, sendo que esta tem de ser pautada em estratos justos, lícitos e fundamentada nos títulos de legitimidade que conferem legalidade a mesma. Sobre esta questão, o jesuíta faz uma distinção entre a escravidão natural e legal, mas ele coloca a sua atenção sobre a questão da escravidão positivada onde se fará uma análise que levará em consideração os títulos de servidão. Nesta perspectiva, sobre a questão do direito de guerra, Molina entende que este tipo de direito é lícito sempre que a guerra for justa e observe os devidos acordos diplomáticos. Logo, sob esta base política, "o vencedor da guerra poderá controlar e dominar o vencido legalmente, isto é algo que não pode ser aplicado quando acontecer a guerra justa entre povos cristãos" (AÑOVEROS, 2000, p.311). Porém, no caso dos povos pagãos estes poderão ser submetidos à servidão perpétua. Simultaneamente, como implicações de delitos de guerra que sejam especificamente graves, o que pode acontecer é a submissão dos dominados ao estado de escravidão.

Em relação ao tráfico de compra e venda de escravos, para Molina três 
aspectos são importantes: (i) a pessoa é detentora de sua liberdade, em razão disto o direito natural permitiria que ela se vendesse como escrava; (ii) o pai pode vender as suas criança em caso de extrema necessidade por um preço justo; (iii) os que vão ser assassinados pelos seus compatriotas podem ser regatados da morte com o valor de uma quantia razoável. Isto desder que tenham sido castigados com justeza, pois assim se transformarão em escravos para que os seus donos não tenham problemas futuros. Outro detalhe importante é o de que as crianças que são geradas por uma mulher escrava também são consideradas escravas. Molina também se detém na análise da compra e venda de escravos negros por parte dos portugueses, nesta perspectiva podemos perceber a articulação do argumento que gira sob o eixo da prática habitual dos reis dos povos africanos, entre si, de subjugação dos povos mais fracos e vencidos nas guerras da parte de povos mais fortes vencedores. Assim, se processava o domínio e a escravidão entre os povos africanos e a venda para os portugueses de escravos, porém evidentemente os portugueses que habitavam entre os povos negros participavam intensamente deste processo de conflito para viabilizar a venda destas pessoas que eram escravizadas. Outro problema moral grave era o de que os roubos em vários povos do continente africano eram punidos com a própria escravidão, sem contar que em reinos como o da Etiópia, o tráfico de escravos era algo regulamentado, pois as pessoas se vendiam ou vendiam os seus filhos para 0 trabalho escravo. As dividas deixadas pelas pessoas que tinham falecido eram cobradas com a escravização dos seus filhos.

Molina elucida o imbróglio de que a instituição da escravidão entre os povos africanos estava amplamente assegurada como prática comum, porém com a invasão dos portugueses esta prática foi sendo sofisticada e potencializada. Neste contexto, o jesuíta nos mostra que se deixou de lado as regulamentações do império e os traficantes é quem contavam os preços tendo em vista o seu enriquecimento. Esta situação gerou uma sociedade desordenada moralmente devido aos excessos de violência, esta circunstância colocou em combate os reis negros que resistiam ao tráfico e os portugueses que pensavam que os reis negros não tinham direito de travar a comprar a venda de escravos. Entretanto, o que conferia licitude e certificava a escravidão dos povos negros era a noção de guerra justa, algo que influenciará muitos filósofos e teólogos do período colonial, isto no que tange "a legitimidade da prática da escravidão e que será um lugar comum entre os autores posteriores" (GONZÁLEZ, 2014, p. 383). Molina desconsidera que exista qualquer tipo de critério de justiça na guerra prática entre os povos africanos, por esta razão o critério de guerras justa não pode ser aplicado a estas realidades. Contudo, reconhece que o dispositivo que regulamente a captura e escravização daqueles contingentes de pessoas que foram postas nesta condição em razão 
de enfrentamentos bélicos com os portugueses, não restava qualquer espécie de dubiedade de que estes precisavam ser escravizados, sendo isto uma implicação a noção de guerra justa.

Ressalte-se aqui que aqueles que estavam na condição de escravos por causa de delitos cometidos podiam ser negociados, sendo isto lícito em qualquer parte, desde que tal escravo tivesse sido condenado pelo poder público tendo em vista o seu delito cometido. Molina faz a distinção nesta matéria ao defender que o delito cometido por uma pessoa não pode ser a razão da escravidão de outras. Paradoxalmente a ideologia da escravidão age aqui, pois mesmo que Molina seja contra a escravização de uma família inteira por causa de um delito leve como o furto tenha sido cometido por um membro desta, o jesuíta prescreve que a regra de que aos portugueses é lícito comprar legalmente aquelas pessoas feitas escravas em razão de terem cometidos furtos deve ser aplicada. E ainda, paradoxalmente, Molina entende que em relação à compra e venda de escravas, as mulheres não podiam ser vendidas e muito menos os filhos e filhas delas, em razão de meros interesses comerciais em adquirir lucro, isto seria legal se apenas acontecesse uma situação de adultério ou estupro, pois ambas as circunstâncias liberariam a venda destas pessoas como escravas. Para Molina, o que se conclui é que se faz legitimo que os povos negros sejam escravizados em razão das normas da guerra justa ou por qualquer outra exceção, porém aqueles que não foram escravizados por isso, esta em situação é de injustiça e fera a racionalidade do direito natural. Logo, torna-se obrigatória a restituição da liberdade e reparação dos danos cometidos a estas pessoas.

Neste ponto, o jesuíta argumenta que aquelas pessoas que compraram escravos neste tipo de condição, precisam estar atentos que possuem escravos sem nenhum tipo de certificação legal. Estas pessoas deviam ter em mente que a compra e venda de escravos ilegalmente gerava uma espécie de pecado mortal, sendo algo que veda o acesso a verdade que leva a construção de uma comportamento moral onde o justo seria a operação de restituir os escravos em termos equitativos. Nesta direção, Molina problematiza o ponto de vista daqueles setores que pensam que a prática escravidão é um método perfeito de evangelização, pois beneficia os povos africanos e os atrai para a fé. O jesuíta não subscreve o pensamento de que a fé possa ser a justificação por excelência para ser normalizar a escravidão, de modo que cabearia as autoridades do poder civil e eclesiástico não poderiam aceitar passivamente tal postura. Sobre a compra de escravos que era algo legitimamente praticado à época, Molina faz uma distinção "entre a primeira e a segunda comprar" (GONZÁLEZ, 2014, p. 384). A sua atenção se com concentra na segunda comprar, pois para ele todos os que compraram escravos de boa fé daqueles que também fizeram tal movimentação baseados na boa fé, fazem isto de uma 
forma lícita. No caso se o dono de escravos que agiu de boa fé alcançasse a certeza de que estes escravos foram injustamente presos, teria o dever de libertá-los e recuperar o dinheiro dos caixas de quem tinha vendido estes escravos.

Temos ainda a distinção que frisa o fato de quem comprar um escravo que venha diretamente da África e que tenha sido colocada nesta situação injustamente, só poderá comprar o mesmo legalmente se este comprar não souber de tal situação e ainda não comprar o mesmo das mãos dos mercadores, sendo este adquirido por pessoas que o compraram de boa fé. A estas pessoas, segundo Molina, é licito ter estes escravos, mas ao que nutrem dúvida sobre a procedência de seus escravos cabe o movimento de restituição do prejuízo dado aos mesmos e deve-se libertar o escravo que está nesta situação de injustiça. Molina tem uma posição procedimental, pois o jesuíta não vive esta experiência existencialmente, de modo que os jesuítas também tinham interesse econômico neste processo de tráfico negreiro realizado pela cora portuguesa de povos negros africanos para mão de obra de trabalho. Esta questão no pensamento de Molina se mostra como algo paradoxal e outros jesuítas também tratam dela como é o caso de Diego de Avendaño. De forma sintética podemos denota que Avendaño trata do tema também de modo procedimental, como algo oficial da Companhia de Jesus e que mesmo que o escravo tenha tido vários donos é lícito comprar o mesmo desde que se siga o procedimento formal e legal do comercia de escravos vigente. Apesar do posicionamento oficialista, Avendaño postula que seja possível justificar a prática do comércio escravagista.

Para este jesuíta, a questão da legalização da escravidão se desdobra no sentido de que para alguns doutores a instituição da escravidão não deves ser encarada como algo de imediato condenável, isto favorece a prática da mesma. Outro aspecto é o de que tanto os filósofos como os teólogos aceitam pacificamente a prática da escravidão, pois é uma prática popularizada no universo colonial. Avendaño indica que a coroa prática a compra e venda de escravos negros e com este comportamento estimula uma cultura escravocrata em todas as instancias coloniais. Assim, o clero não respeita os negros escravizados até o ponto de excomungá-los quando estes cometem o delito do furto sobre os bens de seus donos, e desta forma a legalidade de terem escravos se torna incontestavelmente legal. Logo, para muito os escravos africanos não tem de ter acesso aos direitos, pois a mão de obra deste é fundamental para a sustentação do sistema das repúblicas das Índias. Então, as razões para se manter o sistema da escravidão com algumas regras é de necessariamente central, para que se mantenha o sistema colonial funcionamento, e por isso seria contraproducente que os reis impedissem a prática da escravidão africana, sobre a pena de fazer ruir todo o sistema 
colonial que era muito rentável.

\section{A crítica inovadora presente na proposta antiescravagista de José de Jaca}

Francisco José de Jaca é um frade capuchinho aragonês que tece uma crítica a ideologia da escravidão que se ergue como uma novidade, pois a sua atenção está posta na noção de direito humanos e na ação moral de católicos que sejam pessoas éticas, no sentido de encararem todos os seres humanos como iguais em sua condição de criatura e isto sem nenhuma distinção de raça. A fundamentação de Jaca neste quesito é a ideia de que todas as pessoas foram formadas a imagem a semelhança do próprio Deus. Para Jaca a argumentação bíblica lhe oferece (Gn 1.27), uma ideia do poder absoluto de Deus, pois acontece a revelação temporal ao ser humano de que este na condição de ser sua criatura que faz eco a sua bondade e providências infinitas. Entendendo que foi a divindade a doadora de poder aos seres humanos, não faz sentido algum que exista a dominação escravagista dos humanos entre si. Para Jaca a manutenção da escravidão dos povos africanos é uma violação da condição humana que estes têm em termos universais. Nesta trama, temos a distinção feita pelo frade capuchinho entre o que seja da ardem da lei natural e da lei da graça, algo que indica a motivação de o ser humano ser perenemente agradecido a Deus, pois esta distinção esta presente nas ralações humanas. Jaca denota que a prática da escravidão é um problema que resulta da noção de pecado original e que sendo prática se opõe a condição da natureza humana, se constituindo em uma ideologia que não faz nenhum sentido e que por isso não deve ser praticada.

Nesta perspectiva, Jaca entende que a implicação destas ideias se dá com o direito das gentes onde se fundamenta as relações entre as mais diferentes e diversas comunidades e indivíduos, e da mesma maneira que se faz com o direito natural tem de se construir uma doutrina que estabeleça o que seja o estatuto da lei e da justiça nas relações humanas. O dispositivo da guerra justa é analisado por Jaca no sentido de que esta só pode acontecer se houver a averiguação que entenda que esta seja autentica e legitima. De modo contrário, a guerra justa é feita de modo injusto e se constitui como um roubo e uma tirania. Assim, Jaca argumenta no sentido de elucidar o que seja a legitimidade do emprego da regra de guerra justa. Logo, a validade da guerra justa segue o que a tradição já vinha estabelecendo como sendo legal, ou seja, que este tipo de guerra só pode ser empregada em razão da decisão tomada pela autoridade pública no figura do príncipe ou da república. Jaca coloca em exame a hipótese defendida por aqueles que postulavam que nas terras 
africanas existam guerras ilícitas, e a sua argumentação contrária a esta visão segue a noção de que ninguém averiguou suficientemente sobre tal questão, recolhendo uma série de provas sobre estas guerras e que tenha assim chegado a uma nítida conclusão de que estas guerras internas eram injustas e por isso não podiam ser realizadas.

O que se deve ressaltas, é que Jaca considera que não existe base legal para justificar a impetração da guerra justa e encontra uma série de problemas morais em relação ao tráfico de escravos e venda de vidas como mera mercadoria. Isto era algo que se levantava como plena dificuldade que se mantivesse a continuidade do tráfico de escravos, mesmo que existissem guerras civis entre os povos africanos e que acontecesse a venda entre estes povos das pessoas subjugadas nestas guerras como escravas, tal razão não poderia ser utilizada como justificativa para que se fizesse guerra contra os povos africanos, o fato é que isto "não é motivo para que se admita uma guerra justificada, porém isto sendo empregado feriria todo o direito oposto" (JACA, 2002, p. 11). Outro aspecto que não pode ser utilizado como fator de justificação de guerra é de que ao escravizar os povos africanos negros, estarse-ia ajudando os mesmos a aprenderem viver em sociedade não se justifica. $\mathrm{E}$, muito menos se torna válido o argumento de que com isso estaria se amenizando o sofrimento destes povos ao intervir nos conflitos internos com a prática da escravidão para que não se aniquilem entre si. Jaca não assente a qualquer tipo de argumento que justifique a prática de compra e venda de escravos e nem mesmo aquela distinção entre a primeira compra e a segunda compra destas vidas humanas.

Ao responder as indagações sobre a questão da compra de boa fé, o frade capuchinho argumenta que em negociações não existe boa fé, e mesmo que houvesse boa fé, a exigência de averiguação de a licitude da compra tinha de acontecer e se descobrissem que esta era realmente ilícita, o comprador deveria agir libertando o escravo e restituindo-lhe os danos. Simultaneamente, Jaca postula a noção de que não existe a possibilidade de que haja certa ignorância no comercia de escravos, pois não se deve atentar contra o inalienável direito da liberdade humana. Apenas se consideraria a ignorância válida, se fosse o caso de esta ser encarada como um obstáculo intransponível com aquilo que o ser humano tem em seu domínio. Sendo assim, Jaca argumenta nos sentido de que não é possível a admissão de que a liberdade humana seja passível de captura, pois tanto aquelas pessoas que compram e vendem a liberdade alheia comentem pecado, apenas se este tipo de comércio fraudulento for suprimido é que será possível a extinção do tráfico negreiro. Interessante notar que o frade capuchinho tece uma crítica veraz aos pensadores que não enfrentam o problema de frente, mesmo que estes descrevam os atos violentos que são cometidos com os povos africanos. Ela 
critica o fato de que em seus sistemas de pensamento tratam da questão, mas apenas dando voltas com argumentos retóricos e vazios, evitando assim a tomada de uma nítida posição sobre o problema.

Dada essas suposições, Jaca denota que os argumentos da filosofia moral e jurídica nos mostra que o trabalho escravo forçado dos povos africanos é totalmente injusto. O que se fixa como norma é o fato de que os negros e indígenas são por natureza livres, e mesmo em termos jurídicos estes povos são isentos de todo tipo de trabalho escravo. A linha de pensamento seguida pelo frade capuchinho tem certa afinidade com a tradição de pensamento crítico lascasiana, pois o que importa é que se construa uma proposição da fé que ajuda na remoção deste tipo de estrutura injusta que a ideologia da escravidão estabelece. Entre as proposta do direito canônico e as do evangelho, faz-se mister optar pelo princípios evangélicos. Neste sentido, Jaca pondera que não existe razão de se manter a escravidão dos negros e indígenas, pois as pessoas que são batizadas são filhas da santa igreja. Por esta razão, Jaca se manifesta:

\begin{abstract}
Fazendo a passagem dos direitos humanos que estão sendo tão depreciados, conforme a experiência tem nos mostrado, diante dos fatos que tem acontecido com o povo que tem sido tão desfavorecido, o que se tem é o direito católico com a sua característica piedade. Quero dizer: não existe espeço para a escravidão, nos citados povos negros e os povos originários, principalmente pelo fato de serem cristãos e filhos da Igreja Santa, não sendo isto passivo de ser transformada em uma pena que deve ser aplicada por causa da prática de delitos. De modo que mesmo antes de se falar com estes povos sobre um reino dos céus, os mesmos não eram alvo de maldosa sujeição. Que diremos no caso destes que são filhos da fé católica? Portanto, levando em consideração o que o apóstolo São Paulo nos diz sobre o selo do santo batismo com o sangue de Jesus Cristo, quando afirma que todos os féis não são filhos da escravidão, mas sim da liberdade (JACA, 2002, p. 19).
\end{abstract}

Com a intenção de assevera tal posição abolicionista, não restará para Jaca outra coisa a fazer do que aplicar a doutrina católica, que contava teoricamente com fortes razões para declarar que a prática da ideologia da escravidão se constituía em uma forma ilícita de tratar os povos originários e os povos africanos. A defesa de Jaca é a de que não existe a possibilidade se assentir a ideologia e prática da escravidão no arcabouço do cristianismo. A argumentação do frade capuchinho se dá na direção de erigir uma filosofia e teologia moral que seja de fato consistente diante deste problema. A sua primeira fonte moral é haurida das Escrituras Sagradas, pois tendo em mente que os povos africanos anteriormente ao fato de serem pessoas cristãs, não eram escravas, não faz qualquer sentido que tais pessoas passem a serem 
escravas após a sua introdução como parte do povo de Deus. Logo, a argumentação da prática da guerra justa só teria validade anteriormente ao anúncio da mensagem do evangelho. Na interpretação que Jaca faz da teologia de são Paulo sobre a questão dos servos, aqui não se estaria falando de escravos conforme a lei romana, mas sim estaria se fazendo referência àquelas pessoas que se encontram no seguimento do caminho da fé. Como implicação desta primeira reação crítica, Jaca faz uma análise da injustiça que são inerentes a estas ações, tendo em vista evidenciar o quanto as pessoas cristãs que praticam a escravidão estão deixando de ser referência ética para todas as pessoas ao seu entorno.

Observe-se que, para Jaca a liberdade é uma condição substancial do modo de vida cristão, e partindo desta premissa, deve-se restituir a liberdade dos povos negros africanos para que se revele ontologicamente a sua filiação ao próprio Deus e a santa igreja. Para Jaca, o argumento forte é o de que "se os filhos da igreja gozam da liberdade que a fé lhes confere, logo os negros batizados são filhos da igreja e devem ser alvo da restituição justa de sua liberdade e bens por todos os danos causados a estes povos" (SARANYANA; ALEJOS GRAU, 1999, p. 307). Esta argumentação tem a sua fundamentação posta com base na teologia moral e no direito natural, pois para o frade capuchino a liberdade conquistada por Cristo se estende como herança a todas as pessoas que são filhas da igreja. Avançado em seu pensamento moral, Jaca após firmar as bases da noção de liberdade, cabe agora avaliar e determinar dois critérios que servirão para a realização de distinções diante de situações que se erguem como dilemas, ou seja, ele propõe o ato de avaliar partindo-se dois princípios da piedade e da caridade. Nesta perspectiva, os axiomas da piedade e da caridade se completam, assim a condição de vida cristã complementa a condição da vida humana natural.

O foco de Jaca recai na presente ideia de que a escravidão dos povos africanos é uma práxis e ideologia ilícita, e por esta razão os critérios que são utilizados para a condenação da instituição desta, desconstrói qualquer tipo de justificação da prática da escravidão como algo que deve ser fomentando em razão de já ter-se tornando uma habito comum na sociedade colonial. $O$ tratamento que Jaca confere a esta aporia escravagista, toma como base outro texto bíblico de $(\mathrm{Gn} 3,19)$, onde a questão do fratricídio é um modelo de que quando uma pessoa cristã escraviza outra, o que ocorre é o assassinato da liberdade de sua irmã sendo algo que se constitui em grave problema moral, ainda mais quando se pretende justificar tal práxis desde os critérios de piedade cristã. Assim, o trato desumano e injusto com os escravos africanos e as implicações de postura tirânicas, se mostra como algo concretamente visível nos corpos destas pessoas que eram filhas de Deus. Jaca entende que apesar de toda a opinião pública colonial assentir a ideologia da escravidão, cabe aos 
juízes e aos estamentos eclesiásticos a prerrogativa da autoridade moral em estabelecer a prática da justiça com equidade sem fazer acepção de pessoas. E não existe validade na justificativa de jogar a responsabilidade para estas autoridades afirmando que as mesmas permitem a prática da escravidão.

Desse modo, Jaca aprofunda a sua crítica mostrando como é difícil a vida familiar das famílias africanas escravizadas, pois estas são separadas e impedidas de cultivar a unidade familiar, pois são vítimas da barbárie escravagista cristã, algo que barra a vida matrimonial dos casais no sentido de implosão da vida baseada no sacramento do matrimônio e estabelecendo o despeito da liberdade civil e o ferimento do próprio direito canônico. A preocupação de Jaca com o tráfico e comércio de escravos é candente, pois ele aponta que tal prática gera escanda-los e crueldades nunca antes vistas. Desta forma, os donos de escravos cometem uma dupla infração: (i) abusam da dignidade da pessoa humana; (ii) e cometem o sacrilégio de profanar o sacramento do batismo. Neste sentido as pessoas negras são reduzidas a pura noção de meros objetos que servem apenas como mãos de obra para o serviço de Deus, algo que na visão do frade capuchinho é de uma sordidez sem tamanho. A questão aqui é a de que principalmente o clero que apoia este tipo de barbárie irá ter de dar conta deste tipo de maldade, levando em conta que todos os que praticam a ideologia da escravidão seja comprando, vendendo ou sendo proprietário de escravos também terão de se justificar um dia. Jaca defende que estas pessoas que impõem sofrimentos sore a vida dos africanos, sofrerão o castigo perene em razão de tais atitudes. Logo, aquelas pessoas que agem com base moral na justiça como equidade, terão nítida consciência de que a escravização dos africanos é injusta e implicará em castigos eternos, que já estão sancionados pelo bispo de Roma.

Consideremos que Jaca dá um passo adiante quando leva em consideração a consequências que implicam das ações de abuso cometidas por aquelas pessoas que não refletem sobre o valor das vidas dos escravos. Assim, se defende que:

Portanto, temos que levar em conta a moral católica e sua piedade, que está assentada sob a base apostólica (para a qual não se faz necessário nenhum tipo de rubrica) e que isto seja dito. A ênfase recai sobre a questão de que os negros e indígenas não apenas enquanto cristãos são livres, mas também em seu estado de gentios. Logo, existe a obrigação de restituir a estes povos de uma forma justa a sua liberdade. E, ainda colocar em vigor um tipo de justiça que Ihes restitua com pagamentos tudo aquilo que os seus antepassados, pais, etc., poderiam ter deixado como herança, e com estas heranças estas pessoas escravas poderiam ter prosperado durante este tempo de servidão forçada enquanto perderam tempo trabalhando para os seus donos, e isto sendo algo que lhe deu prejuízo segundo Santo Tomás (Summa Theologiae 2.2 q. 62 art. 4) (JACA, 2002, p. 51). 
O tema da justiça como restituição segundo Jaca se ergue como um critério importante no seu pensamento antiescravagista, pois este serve como uma autêntica referência de verificação do que seja injusto, e que pode ser haurido do direito como uma resolução normativa de justiça. Jaca denota que se existe a tarefa de empregar a justiça como restituição, logo alguns setores da sociedade tem a tarefa de realizar tal imperativo. A sua atenção é direciona para alguns aspectos que são importantes, como é o caso de que os donos de escravos deveriam se desculpar e libertar os negros escravos, pois estes negros teriam boa fé e que ao governo da cora pertencia a prerrogativa de sanar o problema da injustiça. Jaca questionada a ação de escravizar a prole daqueles que cometiam qualquer tipo de delito, pois que culpa teriam estas crianças. Assim, a única razão nítida é a de que a escravidão é uma injustiça. Este debate é encarniçado, pois os donos de escravos têm as suas razões para manter a ideologia da escravidão em curso como uma aparente verdade. Não basta ter boa fé para se justificar a escravidão, porque este critério da boa fé no ato de compra e venda dos escravos não pode ser legitimado pelo fato de terem feito guerras precipitadas e por isso as elegem como critério de operação da escravidão na colônia. Jaca condena tanto a boa fé como as supostas guerras precitadas como uma postura católica incoerente.

A exposição do frade capuchinho ainda trata de observar as razões que são ventiladas pelo jesuíta Diego de Avendaño, que ao ordenar que os títulos e os desenvolvimentos de seus critérios de aplicação urgente onde o rei tem algumas razões políticas inadiáveis, isto serve apenas para os pobres que segundo esta concepção nasceu apenas para prestar serviços, logo esta condição de vileza seria algo que garantiria a existência das Repúblicas das Índias por meio do trabalho escravo destes povos. Jaca denuncia o fato de que os bispos agem em favor dos donos de escravos ao emitir uma série de excomunhões contra estas pessoas pobres, assim sem nenhum escrúpulo estes religiosos e doutores condenam os escravos injustamente. $O$ frade capuchinho não aprova o laxismo de Avendaño quando este tenta justificar os excessos praticados contra os escravos, ele recorre ao direito canônico onde reza a máxima de que "os erros que não são detidos, acabam sendo aprovados e a verdade que se defende de uma forma minimalista, acaba sendo subjugada" (GONZÁLEZ, 2014, p. 391). Para Jaca, não existe a hipótese de que mesmo por razões políticas de urgência máxima vindas da cora, a ideologia da escravidão e sua prática têm condições de ser justificada moralmente. Simultaneamente, o axioma da igualdade e os direitos inalienáveis que atingem objetivamente a vida humana, são inalienáveis e universalizáveis, pois a justificativa de que os pobres tenham nascido para serem escravos não se sustenta diante de tal justificativa da dignidade do valor da vida humana. 
Com base na força do sacramento do batismo que confere a estas pessoas feitas escravas a sua filiação a Deus e sua igreja, serve também para Jaca entender que ao excomungarem os africanos, os bispos estão de conchavos com os seus danos e comentem grave infração seríssima que fere a idoneidade da consciência moral. Assim, a prática da escravidão é uma ação escandalosa, algo que faz Jaca clamar ao rei misericórdia e libertação para os povos escravos africanos. Ele pensa que o governo colonial pode interver para este tipo de injustiça seja barrado, pois o frade capuchinho tem a esperança de o soberano possa interpelar o corpo eclesiástico, e desta forma que "a doutrina cristã seja ensinada, se mostrando como um meio eficaz de formulação de reclamação que vise restituir a liberdade civil africana" (ORAMA, 2015, p. 90). Jaca deixa claro que a intensão dele é a de realizar o serviço missionário da igreja, e a pior implicação da escravidão é a de privar os povos escravizados de receber a graça que confere a fé católica. Jaca por fim, entende que Deus é justo e não coaduna com as maldades e injustiças práticas por causa da ideologia da escravidão.

\section{Considerações finais}

A ideologia da escravidão africana foi combatida por Francisco José de Jaca, mesmo que no ambiente religioso este debate tenha sido encarniçado e mesmo que para Roma tal debate não fez certo sentido durante um bom tempo, muitos de modo individual se beneficiaram do trabalho escravo dos povos africanos. Paradoxalmente a igreja católica em termos institucionais reconhecia a escravidão como uma como uma via lícita para a realização da evangelização. Naturalmente, o império espanhol se valia desta premissa missional para manter a sua dominação e governança da vida em suas colônias. Nesta tarefa missionária o poder civil e o eclesiástico uniram forças para empreender tal gestão. Assim, os missionários não estavam preocupados em questionar este sistema escravagista e muito menos o seu teor ideológico, a tarefa deles era fazer com que acontecesse a conversão dos escravos. A única coisa garantida aos escravos era o ensino da doutrina cristã, esta noção de missão estava jogada em um enorme paradoxo que pesava sobre a tradição cristã, a saber, como é possível a igreja sustentar a liberdade indígena e simultaneamente manter a escravidão dos negros? Esta é uma aporia que move toda a luta deste filósofo e teólogo, em sua luta por justiça para a vida dos povos africanos escravizados.

Por conseguinte, dentro do sistema de conflitos e tensões que se operavam na ardem moral colonial, as proposições e modelos de teologia cristã vigente ao longo de sua tradição milenar, podemos escutar vozes que nem 
sempre concordam com as injustiças, este é o caso de José de Jaca que denuncia a escravidão e escreve uma resolução em favor da liberdade dos negros e dos povos originários. Para o frade capuchinho, além de se ensinar os negros na doutrina cristã, o que também deveria ser feita era a restituição de uma forma justa da liberdade civil dos africanos escravos e o reparo de seus bens materiais. Para Jaca a igreja deveria rever a sua forma de tratar os africanos, pois para ele os povos africanos faziam parte do povo de Deus. Quem escravizava estes povos vindos da África cometia delito grave. Enfim, o que Jaca propõe é uma prática da justiça que seja concretamente ética diante das injustiças causadas pela ideologia e prática da escravidão. Isto implica na exigência de um tipo de restituição justa que está baseada em premissas econômicas, de direitos humanos e o tratamento destas pessoas com a igualde de filhas de Deus, porque acima de tudo elas são livres.

\section{Referências}

AÑOVEROS, J.M.G. Luis de Molina y la esclavitud de los negros africanos en el siglo XVI. Principios doctrinales y conclusiones. In: Revista de Indias, ISSN 0034-8341, Vol. 60, No 219, 2000, págs. 307-330. Disponível em: < https://dialnet.unirioja.es/servlet/articulo?codigo=20028>. Acesso em: 28 jan. 2017.

ARGOTE, G. M.. La filosofia colonial de los siglos XVI, XVII Y XVIII en el nuevo reino de Granada. In: UNIVERSITAS PHILOSOPHICA 23-24, (pp. 11-40), diciembre 1994-junio 1995, Santafé de Bogotá, Colombia. Disponível em: < http://revistas.javeriana.edu.co/index.php/vniphilosophica/article/viewFile/11539 19436>. Acesso em: 17 jan. 2017.

BÍBLIA DE JERUSALÉM: nova edição, revista e ampliada. São Paulo: Paulus, 2002.

BELTRÁN B, D. M. El pensamiento antiesclavista de Francisco José de Jaca, primeras manifestaciones contra la institución de la esclavitud. In: Revista Cuadernos del Caribe ISSN: 1794-7065 | ISSN-e: 2390-0555 | Vol. 17 No. 1 de 2014 | pág. 69-77 San Andrés Isla, Colombia. Disponível em: <http://www.revistas.unal.edu.co/index. php/ccaribe/article/view/50185/50743> Acesso em: 11 jan. 2017.

BRUIT, H. H. Bartolomé de Las Casas e a simulação dos vencidos: ensaio sobre a conquista hispânica da América. Preparação do texto: Katia de Almeida 
Rossini lluminuras. Revisão: Ana Paula Cardoso. Campinas: Editora da Unicamp; São Paulo: Editora lluminuras Ltda., 1995.

GONZÁLEZ, M. A. P. La lucha por la libertad de naturales y africanos en las Indias Occidentales (siglos XVI y XVII). In: Revista española de derecho canónico, ISSN 0034-9372, Vol. 71, № 176, 2014, págs. 369-399. Disponível em: < https://dialnet.unirioja.es/servlet/articulo?codigo=4893257> Acesso em: 27 jan. 2017.

JACA, Francisco José de. Resolución sobre la libertad de los negros y sus originarios, en estado de paganos y después ya cristianos. Ed. Miguel Anxo Pena González. Madrid: Consejo de Investigaciones Científicas, 2002.

LÓPEZ, García José Tomás. (1982). Dos defensores de los esclavos negros en el siglo XVII: Francisco José de Jaca Ofm Cap. y Epifanio de Moiráns Ofm Cap., Caracas, Pontificia Studiorum Universitas a S. Thomas Aq. in Urbe, XV+ 379 págs.

MONTES D'OCA, F. Discurso Antiescravista de Epifanio de Moirans sobre os Títulos de Escravidão. In: Síntese, Belo Horizonte, v. 44, n.139, p. 279-303, Mai./Ago., 2017.

. Two Capuchin Friars in Defense of African Slaves' Liberty: Francisco José de Jaca and Epifanio de Moirans. In: Patristica et Mediaevalia, v. 36, p. 91-108, 2015.

ORAMA, Rebeca Moreno. Entre la retórica legal y eclesiástica: una misión antiesclavista en el siglo xvii. In: Perífrasis. Vol. 6 n.o 11. Bogotá, enero - junio 2015, 140 pp. ISSN 2145-8987 pp 89-104. Disponível em: <http://www.scielo.org.co/pdf/peri/v6n11/v6n11a07.pdf>. Acesso em: 03 fev. 2017.

PICH, R. H. Alonso de Sandoval S.J. (1576/1577 - 1652) and the Ideology of Black Slavery: Some Theological and Philosophical Arguments. In: Patristica et Mediaevalia, v. 36, p. 51-74, 2015.

RAMOS, A. A mestiçagem no Brasil. Tradução e revisão de notas por Waldir Freitas Oliveira. Edufal, Maceió, 2004.

SARANYANA, Josep-Ignasi. A filosofia medieval - das oriegens patrísticas à escolástica barroca - tradução: Fernando Salles. - São Paulo: Instituto 
Brasileiro de Filosofia e Ciência "Raimundo Lulio”, 2006.

Teología en América Latina. Madrid: Iberoamericana; Frankfurt am Main: Vervuert, 1999-2008. 3 v. 